\title{
Social Science and the Citizen
}

\section{U.S.-Soviet Food Connection}

${ }^{66} \mathrm{~S}$ viet agriculture is in deep trouble,' according to Lester $R$. Brown, president of Worldwatch Institute, in a recently released study. Brown notes in $U . S$. and Soviet Agriculture: The Shifting Balance of Power that "Each day two 20,000-ton freighters loaded with grain now leave the United States for the Soviet Union. This massive new food connection may represent the most important change in relations between the two countries since the Cold War began. It demonstrates in clear economic terms that the United States and the Soviet Union need each other."

"The Soviet economy is a planned economy, but their imports were not planned," Brown explains. "Soviet food production shortfalls are rooted in the economic system itself. There is an inherent conflict between a centrally planned, controlled agriculture and a modern, highly productive agriculture. Without fundamental economic reforms, perhaps as great as any since the Communist Party came to power in 1917, even larger Soviet food deficits may be inevitable.",

Soviet food shortfalls, long blamed on weather, are the product of a broad-based deterioration of Soviet agriculture that has been decades in the making, according to Brown. Output of virtually all major farm commodities-including grains, meat, and vegetables-has peaked and begun to decline in recent years. The 1982 grain harvest was down 30 percent from the peak production in 1978. Meat production per person, though bolstered by imported feedstuffs, has fallen 11 percent from the high reached in 1978. Production of potatoes, an all-important dietary staple, was one-quarter below the best year.

"The shortcomings of Soviet agriculture are in striking contrast to the success of American agriculture," Brown asserts. "For U.S. farmers, 1981 was a landmark year. Not only did they harvest a record grain crop, but for the first time they doubled the output of their Soviet counterparts -331 million tons of grain to 165 million tons-despite a much smaller cropland area."
"In addition to being the world's breadbasket, surging U.S. production of corn and soybeans for livestock feed has made the United States the world's feedbag as well. No country has ever dominated world grain trade as the United States does today," says Brown. "Its 55 percent share of world grain exports in 1981 easily overshadows Saudi Arabia's 32 percent share of world oil exports."

Since the partial embargo on U.S. grain shipments to the Soviet Union was lifted, imports of American grain have increased substantially. The flow of grain from the United States is now on the verge of becoming the largest between two countries in history. Overall, Soviet grain imports are nearly double those of Japan, the world's second ranking grain importer.

"The centralized Soviet agricultural system, relying on Five-Year Plans, contrasts sharply with the flexible, sophisticated American agricultural system built around the farmer," Brown notes. "Modern agriculture requires a range of off-farm physical inputs and support services and the authority to make daily on-the-spot decisions. Individual farmers and farm suppliers making these decisions in response to market signals and changing weather and crop conditions have a collective intelligence far exceeding that of a centralized bureaucracy."

Centralized planning and control handicap Soviet farm management in many ways, Brown observes. Having access to the right pesticide at the right time, for example, is often the key to controlling insects, diseases, and weeds. But the Soviet chemical industry in 1981 produced only 60 of the 144 necessary plant protection compounds. More important, the evolution of insect resistance shows little respect for the time lags of Five-Year Plans. Without an agricultural chemical industry continuously altering its products to meet changing needs, Soviet farmers are frequently helpless in fighting an insect infestation or a disease outbreak. Soviet farm equipment and fertilizer industries are plagued with similar shortcomings.

The Soviet leadership has begun to acknowledge these agricultural problems and call for reform, Brown points out. But the new Food Program proposed by the late
Leonid Brezhnev in May 1982 will create still more bureaucratic layers and channels.

A better model for reform can be found in Hungary, which has decentralized its agriculture into self-managing cooperatives and small farms. Ideologically motivated restrictions on small farming and private plots have been swept away. As a result, by 1980 , grain production had doubled that of the early sixties and Hungary once again exported grain.

"The deterioration of Soviet agriculture presents a timely opportunity to lessen tensions between Washington and Moscow," Brown concludes. "While not ensuring peaceful relations between the two countries, the food connection will make massive arms spending more difficult to justify. The American people may increasingly doubt that a country depending on the United States for so much of its food could be as dangerous as commonly portrayed. Hardliners in the Soviet Union may be unable to convince Kremlin colleagues that the country feeding them is indeed a mortal enemy.",

The entire world has a stake in avoiding a U.S.-Soviet nuclear exchange that would decimate North America's exportable grain surplus, Brown said. Such a catastrophe would leave over a hundred grain importing countries, most of them in the Third World, scrambling for the exports of Australia and Argentina plus a few other small exporters. As a result, more people might die of starvation in the South than of radiation in the North.

"The importance of the dramatic shift in the agricultural balance of power lies less in using food as a political lever than in the psychological effect new commercial ties will have on how the two superpowers relate to each other. The long line of grainladen ships linking U.S. farms with Soviet dining tables represents a major new economic relationship, one that could eventually transform their political relations as well."'

\section{Correction}

The text of the letter on Yugoslavian dissidents in the November/December 1984 issue of Transaction/SOCIETY was attributed to Mihailo Marković in error. 